\title{
LEPOTNI IDEAL V UPODABLIANJU MARIJE V FLORENTINSKEM SLIKARSTVU DRUGE POLOVICE 15. STOLETJA
}

Ključne besede: lepotni ideal, florentinska renesansa, Marija, renesančno slikarstvo

Florentinsko slikarstvo 2. pol. 15. st. predstavlja enega od vrhuncev v tradiciji marijanskih upodobitev. Temu botruje priljubljenost Marijinega čaščenja, ki je dediščina gotskega obdobja, ko Marijo predstavljajo v verniku bližji vlogi ljubeznive in usmiljene matere ter ponižne in skromne device, ki sprejema Božjo voljo. Ob malone nepregledni množici Marijinih podob se zastavlja vprašanje slogovnega razvoja in $\mathrm{z}$ njim povezanega lepotnega ideala $\mathrm{v}$ florentinskem slikarstvu zgodnje renesanse. Marijanske upodobitve $\mathrm{v}$ florentinskem slikarstvu 15. st. se delijo na idealizirane in manj idealizirane oz. realistične. Realistične interpretacije nastajajo zlasti v 1. pol. 15. st., v 2. pol. pa prevlada idealizirana Marijina podoba, zato se $\mathrm{v}$ tem času realistična podoba pojavlja $\mathrm{v}$ manjšem obsegu. Zastavljajo se vprašanja, zakaj prevlada idealizirana Marijina podoba, kakšna so izhodišča slikarjev in kakšen je razvoj lepotnega ideala.

Za razumevanje idealizirajočega toka $\mathrm{v}$ marijanski umetnosti 15 . st. moramo poznati tudi realistični tok, ki predstavlja osnovo in antipod prej omenjenemu. Realizem bi lahko opredelili kot slikanje po naravi oz. čim zvestejše upodabljanje resničnosti. Realistične interpretacije upodabljajo Marijo kot žensko iz vsakdanjega življenja, neolepšano, preprosto, včasih celo neprivlačno. Odločitev za takšne upodobitve lahko razumemo kot reakcijo na idealizirano varianto mednarodne gotike, ki je Marijo predstavljala kot mistično, nežno in milo, zglajenega obraza in lahkotnega telesa, 
torej ne kot zemeljski ampak kot nebeški lik. Ne smemo pa pozabiti na giottovsko tradicijo, ki goji bolj plastičen in voluminozen marijanski lik, vendar jo lahko razumemo le kot predstopnjo zgodnjerenesančnega realizma, ko se fiziognomije zmehčajo, telesa pa organsko zlijejo s prostorom.

Slikarji so si prizadevali ustvariti marijansko figuro, ki bi dajala vtis resničnosti, pri čemer so upoštevali opazovanje narave in najnovejša spoznanja o anatomiji, voluminoznosti, reliefnosti in $\mathrm{z}$ njo povezanim vprašanjem svetlobe in sence ter čustvenem izrazu, svoje znanje so opirali tudi na sočasne ali nekatere gotske kiparske rešitve. Tako je nastal pravi antipod zasanjani, elegantni interpretaciji mednarodne gotike, ki je kljub določeni meri neprefinjenosti in mestoma robatosti deloval izredno neposredno, saj je figura v svoji prepričljivi telesnosti stopila pred gledalca in ga soočila s svojo fizično prisotnostjo ter psihološko poglobljenostjo.

Vodilno ime tega toka je Masaccio, ki z upoštevanjem zgoraj naštetih izhodišč ustvari monumentalen, plastičen marijanski lik z resnim, melanholičnim izrazom, ki se izkaže za poglobljeno in večplastno predstavitev notranjega doživljanja (slika 1).

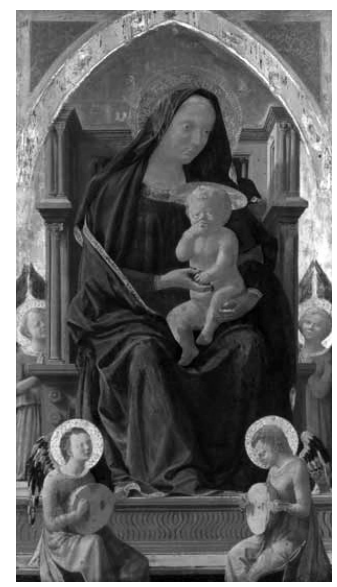

slika 1: Masaccio: Marija z otrokom, 1426, London, National Gallery vir:http://www.nationalgallery.org.uk/cgi-bin/WebObjects.dll/

CollectionPublisher.woa/wa/work?workNumber=ng3046 
Voluminoznost telesa, ki je polno življenjske moči, je primerljiva z Giottom in njegovimi nasledniki. Za Masaccia je bilo pomembno sočasno kiparstvo, ki je zlasti z Donatellom odpiralo novo poglavje v upodabljanju človeškega telesa. Masaccio je občudoval njegov smisel za realistično obravnavo telesa, ekspresivnost $\mathrm{v}$ obrazih ter piramidalno kompozicijo. Nekaj časa je preživel v Ghibertijevi delavnici, kjer se je naučil anatomske natančnosti (Radke, 2002, 51, 54; Durant, 1953, 100). Poleg sočasnega kiparstva je potrebno omeniti toskansko plastiko 2. pol. 13. in 14. st., ki zlasti z Nicolo in Giovannijem Pisanom ter Arnolfom di Cambiem izoblikuje voluminozno obravnavo človeške figure. Lokalna kiparska tradicija je Masacciu nudila mojstrske rešitve v upodabljanju človeške figure, vpliv slednjih lahko vidimo v njegovih likih, ki delujejo kot kipi, preneseni v slikarski medij. S svojimi marijanskimi interpretacijami je vplival na Uccella, mladega fra Lippija, Domenica Veneziana in druge (Borsi, 1994; Masaccio e le origini del Rinascimento, 2002; Holmes, 1999).

Moč realizma se kaže v predstavljanju prisotnosti Matere božje v domala otipljivem telesu in lepoti duhovne globine. Lahko bi ga povezali z vero $\mathrm{v}$ resnično prisotnost Marije na krajih njenega čaščenja, saj omogoča vizualno izkušnjo navideznega neposrednega stika vernika $\mathrm{z}$ njo. Richard C. Trexler meni, da so Florentinci v 15. st. sliko razumeli kot ekvivalent resnični prisotnosti, še več, verjeli so, da hoče sveta oseba videti obraz molivca (Trexler, 1987, 32). Za Florentince 15. st. je bila vizualna predstava sakralne tematike izjemno pomembna, o čemer pričajo tudi procesije in sacra rappresentazione (Holmes, 1999, 23-57). Slednje naj bi bile dodaten razlog za razvoj realističnega sloga, saj so zahtevale veliko mero realističnega v uprizarjanju, da jih je gledalec sprejemal kot verjetne.

Realistični tok se je pojavil kot znanilec sprememb na florentinskem likovnem prizorišču v 1. pol. 15. st., vendar se v kasnejših desetletjih 15. st. v Firencah ni uveljavil v takšni meri, kot bi mogoče pričakovali. Razlog za to je najbrž v tem, da ni uspel zadostiti želji po idealni telesni lepoti. Ob tem se sprašujemo, zakaj je potrebno Marijo naslikati kot poudarjeno lepo žensko tudi v telesni podobi. Mar ni dovolj njena notranja lepota, ki je popolna in daleč nad človeško? Navsezadnje telesna lepota lahko vzbudi neprimerne 
odzive, ki žalijo osebo Matere božje in vernika pahnejo v greh, kar je ravno nasprotno, kar naj bi z Marijino podobo želela doseči cerkev in umetnik. ${ }^{1}$

Odgovor na to je potrebno iskati v človeški naravi kot tudi v florentinski družbi 15. st. Razlago za prvo ponuja florentinski renesančni neoplatonistični filozof Marsilio Ficino, ki pravi, da je čut za lepoto človeku prirojen in da tisto, kar se čim bolj približa temu čutu, človek opredeli kot lepo (Ficino, 2003, 277). Kenneth Clark meni, da je človekova nagonska želja, ne posnemati, ampak izpopolnjevati, kar pojasnjuje kot del dediščine antičnih Grkov, ki jo predstavlja Aristotelova misel, da umetnost dopolni, česar narava ne more, in da nas umetnik opozori na neizvršene zaključke narave (Clark, 1956, 9). Torej je del človekove narave, da išče, prepoznava in občuduje lepo ter ga tudi ustvarja.

Zunanja lepota je bila kot del reprezentativne podobe pomembna in močno želena kvaliteta $\mathrm{v}$ tedanji florentinski družbi. Lepotna merila je bilo moč najti tako v literaturi kot poeziji, filozofiji, umetnostni teoriji, pravilih vedenja in likovni umetnosti. Vzrok za homogeno zlivanje estetskih nazorov je tudi v druženju predstavnikov teh področij, ki so se srečevali bodisi v okviru Platonske akademije bodisi na medičejskem dvoru, kjer jih je gostil Lorenzo Medičejski, ki se je rad obdajal z umetniki in intelektualci. Estetski nazori so se tako izmenjavali in dopolnjevali, umetniki pa so jih prelivali v likovni jezik. V Firencah 15. st. je veljal petrarkistični lepotni ideal, vpliv katerega na likovno umetnost je bil velik, saj je svetlolasi ženski lik prisoten skozi celo 15. st. in zlasti v 2. pol. 15. st. slikarji dosledno upoštevajo poetične opise zunanjosti. Toliko bolj pa so ta lepotna določila veljala za upodabljanje Marije, najlepše med ženami, saj so njeno telesno lepoto že prej dojemali kot odsev notranje, kar se je stopnjevalo z mišljenjem v tedanjem florentinskem okolju.

1 Giorgio Vasari pripoveduje o slikarju, znanim pod imenom Il Nunziata, od katerega je naročnik zahteval, naj naslika Marijo tako, da bo poštena, stara in v njem ne bo zbujala poželenja. Slikar je zato Mariji naslikal brado (Vasari, Le vite, VI, 535-536), Leonardo da Vinci pa piše o možu, ki je kupil neko njegovo sliko s sakralno tematiko in se zaljubil v upodobljeno figuro. Leonarda je prosil, naj odstrani simbole božjega, da bi jo lahko brez skrbi poljubljal. A naposled je njegova vest premagala slo in sliko je odstranil iz hiše (Richter, 1939, 64). 
Eno izmed izhodišč, ki opravičuje predstavljanje Marije kot lepe, predstavlja Visoka pesem, kjer je nevesta predpodoba Marije kot Kristusove neveste. Ženin večkrat nagovori nevesto kot lepo, zlasti pa so z Marijo povezovali verz »Vsa si lepa, prijateljica moja, in madeža ni na tebi« (Vp 4, 7). Visoka pesem podaja metaforični opis neveste, iz katerega lahko izluščimo nekaj konkretnejših detajlov (npr. škrlatne ustnice, bele zobe, rdeča lica, dolg vrat, kodraste lase, vitko postavo), ki pa dopuščajo svobodno likovno interpretacijo.

Opise Marijine zunanjosti je sprožila trditev sv. Ambroža, na katero opozarja Jure Mikuž, da je njena telesna lepota odsevala lepoto njene duše (Mikuž, 1999, 37). Ti opisi izvirajo zlasti iz vzhodne cerkve, kjer so njeno zunanjost dojemali kot identifikacijo $\mathrm{z}$ resnično Materjo božjo ${ }^{2}$ (od tod izvira tudi prepričanje o verodostojnosti Marijinega portreta, ki naj bi ga naslikal evangelist Luka), medtem ko zahodna cerkev Marijinemu videzu ni pripisovala takšnega pomena, kar ponazarja misel sv. Avguština v VIII. knjigi De Trinitate, kjer pravi, da Marijinega obraza ne poznamo(Aurelius Augustinus, De Trinitate, VIII, 5.7). Iz te trditve lahko razberemo, da Marijin videz za vernike ni bil tako pomemben, prej njena ljubezen in dobrota, ki sta ključni, ko se vernik obrača nanjo v molitvi, kar pa ne pomeni, da se o njenem videzu ni razpravljalo, navsezadnje je bila to precej običajna snov pridig. ${ }^{3}$ Tako se odpre nešteto možnosti za upodabljanje Marije, a hkrati tudi spoznanje, da nobeno delo ne bo prikazovalo njene prave podobe. Umetniki so imeli dokaj proste roke, vendar so razmere v florentinskem slikarstvu 2. pol. 15. st. precej specifične, saj je ženski lepotni ideal zelo neposredno opredeljen s strani umetnostne teorije, sočasne filozofije, poetične tradicije, teoloških del in družbenih norm. Isti lepotni ideal se uporablja ne le za Marijo ampak

2 V 9. st. je grški menih Epifan podal Marijin opis v delu Življenje Device (gl. Epifan, cit. v: Vogtlin, A., Vita b. v. Mariae et Salvatoris rythmica, Bibliothek des literarischen Vereins $z u$ Stuttgart, CLXXX, 1899), ki je služil kot vir grškemu avtorju iz 1. pol. 14. st. Nikeforu Callistusu Xanthopoulosu za njegov opis Marije (gl. Ecclesiasticae Historiae libri decem et octo Frankfurt, 1588, II, xxiii), od koder ga je 1570 povzel Johannes Molanus, profesor teologije v Louvainu (gl. De Historia Sanctarum Imaginum et Picturarum, II, lvii, Louvain, 1571, 163-169). Opisi Marijine zunanjosti so postali zanimivi za zahodno teološko in nabožno literaturo šele pred koncem 16. st., saj se prej za Marijino identiteto niso zanimali. Gl. Belting, H., Likeness and Presence. A History of the Image before the Era of Art, Chicago, 1994, 305.

3 Npr. pridiga o Marijini lepoti dominikanskega meniha Gabriela de Barlette, kjer razpravlja o njeni polti. Gl. Gabriel de Barletta, Sermones celeberrimi, I, Benetke, 1571, 173. 
tudi za druge ženske like tako iz sakralnega kot profanega konteksta. Slednje potrjuje, kako močno je bil ta ideal dodelan in vpet $\mathrm{v}$ tedanjo družbo.

Za renesančno pojmovanje lepega velja, da se lepa zunanjost povezuje $\mathrm{z}$ lepo dušo - ta miselnost je prisotna tako $\mathrm{v}$ umetnostni teoriji, poeziji kot filozofiji, teoloških delih in priročnikih vedenja. To se v celoti ujema $\mathrm{s}$ predstavo o Mariji, ki je brez greha in najlepša izmed žena. Slikarji so se pri marijanskih upodobitvah ravnali po tem merilu in tako razvili jasno izoblikovano različico ženskega oz. marijanskega lepotnega ideala.

Kakšen lepotni ideal v upodabljanju figure razvije tedanja umetnostna teorija, najbolje predstavita Albertijevo delo O slikarstvu (1435) in Leonardov Traktat o slikarstvu (izšel je šele 1651), za opredelitev lepote je pomemben tudi Albertijev traktat $O$ arhitekturi (1452, izšel 1485). Oba se navdušujeta nad naravo kot najboljšim možnim virom slikarske umetnosti, pri čemer je Leonardov poudarek nekoliko večji kot Albertijev. Narava jima služi kot edini pravi vir lepega, a hkrati opozarjata, naj slikar vedno izbere najlepše iz nje (Alberti, 1966², 94; Leonardo da Vinci, 2005, 50, zapis 55), kar Alberti utemelji, rekoč: »...nikdar ne najdemo popolnih lepot $v$ enem samem telesu, temveč so le-te redke in razpršene v mnogih telesih." (Alberti, $\left.1966^{2}, 92-93\right)^{4}$ Leonardo priporoča slikarju, naj izbira »dobre plati številnih lepih obrazov« (Leonardo da Vinci, 2005, 79, zapis 134). Medtem ko skuša Alberti zvesti lepoto v splošno veljavno merilo, lepotni ideal, ki nastane na podlagi izbora najlepših telesnih delov več različnih figur, pa je Leonardo bolj sproščen in dopušča večjo pestrost v lepoti oz. meni, da je lepota raznolika (Leonardo da Vinci, 2005, 80, zapisa 137, 138).

Oba sta naklonjena preprosti, asketski podobi lepega, medtem ko vsakršen okras odklanjata kot pomožno lepoto, ki ni tako prepričljiva kot naravna, ki jo srečamo npr. v podobi lepih žensk (Alberti, 1966, VI, 2; Leonardo da Vinci, 2005, 181, zapis 398).

Pri presojanju lepote dajeta prednost splošno veljavnemu mnenju pred subjektivno oceno, saj utegne biti slednja zavajujoča in posledično lahko pri-

4 Antični grški slikar Zevksis, ki je v svetišču na otoku Krotonu slikal trojansko Heleno, naj bi si izbral pet najlepših domačink in najlepše dele $\mathrm{z}$ njihovih teles združil v podobi lepe Helene. 
vede do sloga slabše kakovosti. Alberti lepoto pojmuje kot obliko »harmonije in skladnosti med telesnimi deli glede na določeno število, obris in razporeditev, kakor zahteva simetrija, temeljni in absolutni zakon narave" (Alberti, 1966, IX, 5). Oba avtorja predstavita lepotni kanon, pri čemer se naslanjata na antično grško umetnost, ki s Poliklejtom na čelu meni, da morajo človeški obliki vladati številke in harmonična številčna razmerja, saj naj bi le-te in njihova racionalna zaporedja vsebovali moralne in morda magične moči. Ena od besed za moč je bila simetrija $\mathrm{v}$ pomenu sorazmernosti, pod katero so si predstavljali v predmet vgrajen modul, ki narekuje vse mere $\mathrm{v}$ celih racionalnih številih. ${ }^{5}$ Albertijevska figura meri 7,5 dolžin glave oz. 8 4/7 dolžin obraza, leonardovska 8 dolžin glave oz. 10 obraznih dolžin, kar se ujema z Vitruvijevim sistemom telesnih proporcev (Vitruvij, 1999, 54-55). Albertijevska figura je manjša kot leonardovska, a očarljivo ljubka, leonardovska je umirjeno elegantna. Oba proporcionalna sistema so slikarji uporabljali za Marijin lik, prvega zlasti fra Lippi in mladi Botticelli, v 2. pol. 15. st. pa je prevladal drugi (npr. pri Botticelliju, Leonardu, Ghirlandaiu, Filippinu Lippiju).

Oba poudarjata pomen senčenja oz. reliefa, imata ga za pomembnejšega od barve. Senco opredelita kot »dim«, a Leonardo se razlagi sence (kot tudi postopku njene izdelave) temeljiteje posveti in sfumato predstavi kot sredstvo za upodabljanje lepote: »Mišice naj ne bodo ostro nakazane, marveč naj se mehka svetloba nezaznavno končuje v prikupnih in prijetnih sencah, iz česar nastaneta ljubkost in lepota." (Leonardo da Vinci, 2005, 142, zapis 287) Slikarjem svetuje, naj figuro postavijo v temnejši prostor oz. na prehod iz svetlejšega v temnejši prostor: »...zaradi takšnega stopnjevanja senc je obraz zelo plastičen; $v$ osvetljenem delu so sence skorajda neopazne in $v$ senčnem skoraj ni zaznati svetlobe. S takšnim prikazovanjem in stopnjevanjem senc in svetlobe pridobi obraz veliko lepote." (Leonardo da Vinci, 2005, 64, zapis 90) Takšen način senčenja je Leonardo spoznal v Verrocchievi delavnici. Ohranili sta se Verrocchievi risbi ženskih glav, od katerih je ena v Oxfordu (Christ Church College), druga v londonskem British Museum (sliki 2 in 3): obravnava polti je subtilna, kiparsko znanje je prenesel v risarski medij,

5 Beseda »kanon « ima več pomenov, v grščini pomeni trs, zaznamovan na enakih razdaljah, ki se uporablja za merjenje (Hersey, 1996, 43-44). Besedo v današnjem pomenu so uporabljali v antični grški umetnosti. 
kar je razvidno iz dovršenih prehodov med svetlimi in temnimi partijami obraza, ki se zlagoma stopnjujejo z mehko megličasto senco. Tako doseže ne le plastičnost oz. reliefnost temveč tudi lepoto in milino v izrazu. Leonardo je kot njegov najbolj talentiran učenec prevzel ta način senčenja, ga prenesel $\mathrm{v}$ slikarstvo in razvil do popolnosti.

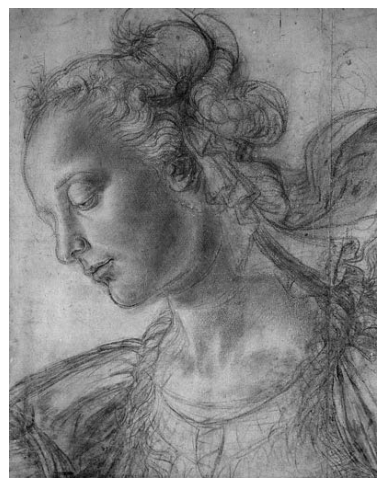

slika 2: Andrea del Verrocchio: Ženska glava,

Oxford, Christ Church College vir: Rubin, Wright (1999)

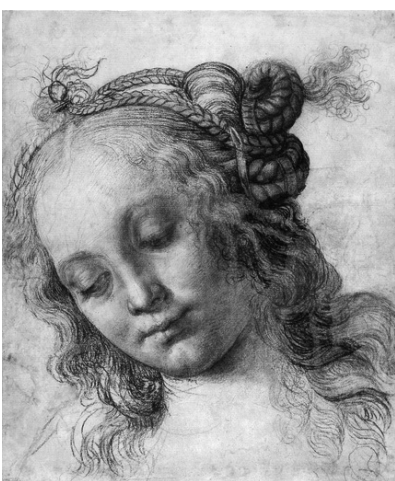

slika 3: Andrea del Verrocchio: Ženska glava, London, British Museum vir: Rubin, Wright (1999)

Pri obeh avtorjih zasledimo misel, da je lepa duša pogoj za lep videz. Notranja občutenja, ki so del duše in ki jih imenujeta vzgibi duše, se navzven izražajo z gibi, notranja lepota se kaže v kretnjah figur. Leonardo je prepričan, da "figura ne bo vredna hvale, če ne bo v največji možni meri v dejanju izražala občutenja svoje duše " (Leonardo da Vinci, 2005, 168, zapis 364). Oba dajeta prednost razgibanosti likov in poudarjata, da morajo biti gibi figur ljubki, drže prijetne in elegantne, kar zopet potrjuje idealizacijo vzorov iz narave (Alberti, 1966², 80; Leonardo da Vinci, 2005, 167, zapis 356). Za Marijo so bili primerni dostojanstveni in umirjeni gibi, saj je bila takšna tudi njena duša. Walter Simons opozarja na zapis sv. Avguština o Marijinem značaju: "Ničesar prevzetnega ni bilo v njenem bežnem pogle$d u$, ničesar žaljivega $v$ govoru, ničesar nespodobnega $v$ njenih dejanjih. $\mathrm{Ni}$ bilo objestnih gibov, ne razbrzdanega koraka, niti ni bil njen glas čemeren; ker narava telesa odseva dušo, je bila prava podoba skromnosti.«(Simons, 1994, 10-23). Takšna podoba je tradicionalna v teološkem pogledu, lahko 
jo povežemo s svetopisemskimi opisi njenih dejanj, ki so izraz ponižnosti, ljubezni in usmiljenja. Florentinsko slikarstvo 2. pol. 15. st. jo predstavlja na ta način, Marija je kot ideal miline in ljubezni dober primer povezave telesa in duha, njen duh preveva dobro, kar se izraža v mirnih, preudarnih kretnjah. Običajno je upodobljena kot ideal nesebične materinske ljubezni, kar se kaže v srečnem žarenju njenega obraza, ki zrcali ponotranjeno doživljanje milosti, biti mati. Mestoma jo upodobijo nemirno, predvsem $\mathrm{v}$ motivu oznanjenja, ki se v tem času ikonografsko razdeli na pet Marijinih stanj, conturbatio oz. nemir ustreza prvemu izmed njih. ${ }^{6}$

Leonardo in Alberti v shemo lepotnega ideala umestita tudi pričeske. Medtem ko Alberti zagovarja valovanje las, ki ga primerja $\mathrm{z}$ drevesnimi vejami, kačami in plameni, je Leonardo zadržanejši in predlaga, da so lasje spleteni v kite, le rahlemu vetrcu dovoli, da se ujame v kakšne kodrčke (Alberti, 1966², 81; Leonardo da Vinci, 2005, 181, zapis 398). Slikarji so Marijo upodabljali tako $\mathrm{z}$ valovitimi kot spetimi lasmi in kodrčki, enako situacijo srečamo na sočasnih ženskih portretih in drugih ženskih likih.

Medtem ko se umetnostna teorija ukvarja $\mathrm{z}$ vizualnim predstavljanjem lepote, pa se florentinska neoplatonistična filozofija osredotoča na opredeljevanje lepote kot duhovne kategorije. Marsilio Ficino lepoto razlaga v okviru platonske tradicije kot idejo, ki biva v svetu idej in se v čutnem svetu kaže kot telesna lepota. Lepota teles ni popolna, saj so le posnetki ideje, ki je prva po vrsti in kot taka popolna, vse, kar nastane po njej, pa te dovršenosti ne doseže, ampak je zgolj njen približek. Ficino lepo povezuje z dobrim, »kajti duše in umi so v sebi grdi, razen če jih ne oblikuje dobro, čigar sijaj je lepota“ (Ficino, Platonic Theology, XI, iv, 2), še več, izenači ga z bistvom dobrega oz. z Bogom. Bog je vrhovna lepota, lepota, ki je obstajala že v začetku (Ficino, Commentary on Plato's Symposium on Love, VI, 17), svet kot njegova stvaritev pa je odsev njegove podobe: »Senca Boga je takšna, da je najlepša izmed čutnih stvari.«(Ficino, Platonic Theology, IX, iii, 4) Zato je v vidnem svetu narava podoba lepega in umetnost, ki črpa iz narave, približuje dušo njenemu božanskemu izvoru. Na tem mestu pridemo do stične točke z Leonardom, ki prisega na naravo kot edini pravi vir lepote oz. jo pojmuje kot lepoto.

6 Več o tem gl. Baxandall $(1996,65-66,70)$. 
Posebno mesto v Ficinovi filozofiji zavzema duša, ki v sebi nosi čut za lepoto kot nekakšen pečat, $s$ katerim je zaznamovana že ob stvarjenju. Ideja lepote bi bila sama sebi namen, če se ne bi uresničila v materialnem, čutnem svetu, saj jo le tako duša, ki je ujeta $\mathrm{v}$ snovno telo, lahko prepozna in zahrepeni po vzvišeni lepoti. Ficino v lepoti vidi privlačno silo, ki dušo vabi k sebi (Ficino, Opera, 297). Hrepenenje duše po lepoti je ljubezen, ko se hoče dvigniti k Bogu in zreti njegovo lepoto (Ficino, Opera omnia, II, 1362), se v njej izgubiti. Duša v združitvi z Bogom vidi smoter svojega obstoja: "Lepoto bi lahko imenovali en in isti krog, saj se začenja v Bogu in Bog jo privlači [zopet nazaj k sebi]. ${ }^{7}$

Svoj prispevek k marijanskemu lepotnemu idealu je dala tudi sočasna poezija medičejskega kroga, ki predstavlja idealizirano podobo ženske. V delih najpomembnejših pesnikov, kot so Luigi Pulci, Agnolo Poliziano in Lorenzo Medičejski, najdemo podrobne opise junakinj ter hvalo njihove telesne in duhovne lepote. Tovrstna pesniška tradicija ima svoje začetke $\mathrm{v}$ trubadurski liriki, kjer so opisi žensk sorodni, a običajno manj natančni, v posameznih detajlih se ujemajo z mlajšimi (npr. lepa ženska ima zlate oz. svetle lase, mil obraz, mil in kreposten značaj). Trubadurska lirika za razliko od mlajših pesniških tradicij izpostavlja čutni aspekt ljubezni, kamor sodi tudi telo opevane dame. Kasneje čutna komponenta postane bolj vzvišena, kar za seboj potegne tudi sublimnost pesniškega izraza. ${ }^{8}$ Spremembe v pogledu na opevano žensko prinesejo pesniki sladkega novega stila, ki svoje gospe povzdigujejo v angelska bitja in občudujejo njihovo plemenito srce. Posebno mesto zavzema Dantejeva Beatrice, pri kateri sta pomembni njena krepost in ponižnost oz. duša, medtem ko o njenem videzu ne izvemo veliko. To tradicijo nadaljuje Petrarka, ki svojo Lauro predstavi kot krepostno damo, njeno zunanjost opiše metaforično, kar poudari vzvišeno, distancirano pozicijo. Ti metaforični opisi (npr. "Zlato bilà je glava, sneg vroč lice, / eben obrvi, dvoje zvezd oči [...], / biseri v rožah usta ... « [Petrarca, Soneti in kancone, 49]) postanejo osnova za nadaljnji razvoj idealizirane podobe ženske, saj petrarkistični lepotni ideal prevzamejo in dopolnijo mlajši pesniki.

7 Ficino, cit. v: Panofsky, E., Renaissance and renascences in Western art, New York, 1972, 185.

8 Gl. Pintarič, M., Trubadurji, Ljubljana, 2001, 131, 143, 150. 
Konkretnejše opise prinese Boccaccio, njegova ženska je še vedno idealizirana, vendar je dostopnejša, njena zunanja lepota je natančno podana. ${ }^{9}$

Iz te dediščine črpajo poeti medičejskega kroga. Ženske, ki jih opevajo v svojih delih, imajo precej skupnega: lepa ženska je svetlolasa in bele polti, ima široko čelo, temne obrvi, oblikovane v loku, sijoče temne oči, ljubek nos, rdeča lica, majhna usta in rdeče ustnice, bele zobe, okroglo, čvrsto brado $\mathrm{z}$ jamico na sredi oz. zarezo, dolg vrat, ozka in okrogla ramena, dolge roke, vitek pas, dolge noge in majhna stopala. Njena postava je skladna in ljubka. Je prijetnega značaja, dobrosrčna, usmiljena in krepostna. Njen smehljaj priča o radosti in ljubeznivosti. Lepa ženska je razumna, modra, inteligentna ter pobožna. Njene besede so sladke in prijetne ušesom. Celoten vtis je ljubek oz. sladek. ${ }^{10}$

Ena od značilnosti poezije medičejskega kroga je povezava lepote $\mathrm{z}$ melanholično noto, ki jo pozna petrarkistično pesništvo. Zasledimo jo zlasti v Polizianovem delu Stanze per la giostra di Giuliano de’ Medici, ki je nastalo kot spomin na viteški turnir, prirejen 28. januarja 1475 v Firencah. Ena izmed likov je nimfa Simonetta, mila lepotica, ki pa umre, kar globoko užalosti njenega viteza, junaka turnirja Iulia. Poetična lika se nanašata na Simonetto Vespucci in Giuliana Medičejskega ter njuno platonično ljubezen. Simonetta je umrla leta 1476, njena smrt je sprožila val pesmi, ki so opevale njeno lepoto in krepost (Dempsey, 1992, 117). ${ }^{4}$

Petrarkistični lepotni ideal je predstavljal močan impulz v likovni umetnosti, saj je prevladoval na marijanskih upodobitvah v 2. pol. 15. st. v Firencah, gojili so ga vsi vidnejši florentinski umetniki. Močno je zaznamoval tudi sočasno portretno umetnost (slika 4), ki dokazuje, da so ženske prilagajale svoj videz tem lepotnim merilom (lase so si svetlile z belilom ali so jih izpostavljale sončnim žarkom, da bi bilo čelo elegantno, so si brile lase, pulile so si obrvi ter posegale po rdečilu za ustnice).

9 Gl. Boccaccio, G., Teseida delle nozze d’ Emilia (ed. Roncaglia, A.), XII, 53-63, Bari, 1941, 356-359.

10 Prim. Pulci, Morgante, XV, 99-104, Poliziano, Stanze per la giostra, I, 43-45, 50, Poliziano, Ballate, VI, Lorenzo de' Medici, La Nencia da Barberino, 3-5, 7, 9-10. 


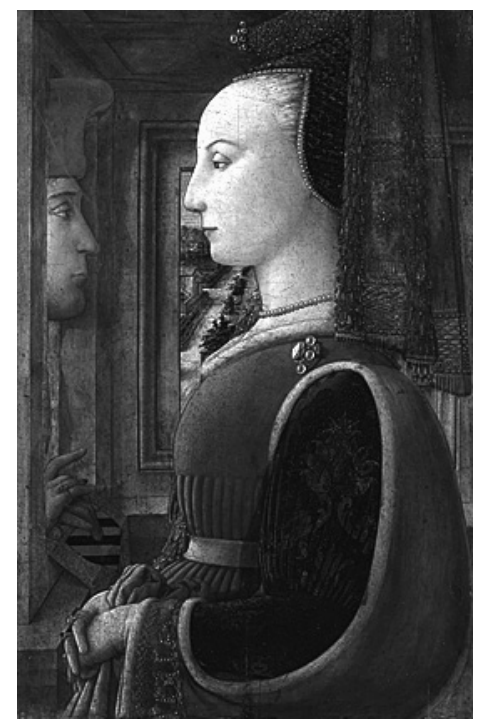

slika 4: Filippo Lippi: Portret ženske in moškega, ok. 1438-1444,

New York, The Metropolitan Museum of Art vir: Ruda (1993)

Lepa zunanjost pa je bila odsev notranje lepote, za najvišjo žensko vrlino je v tedanjih Firencah veljala krepost. Florentinski ženski portreti 15. st. so večinoma nastajali ob poroki ali rojstvu otrok, ki sta bili najpomembnejši prelomnici v življenju tedanjih Florentink, zato je bila krepost izpostavljena kot njihovo najodličnejše znamenje. Pod pojmom kreposti razumemo deviškost, sramežljivost, poštenost, skratka čistost telesa in duha, v širšem kontekstu tudi intelektualno moč, odličnost, nadarjenost. Veljalo je, da je krepostna ženska lepa na pogled, kar pa je lahko slikarjem predstavljalo težavo, saj je morala biti upodobljenka naslikana kot lepa, četudi morda ni bila, sicer bi se zdelo, da ne premore lepe duše (Brown, 2001, 13) ${ }^{15}$ Portretiranke so večinoma upodobljene v strogem profilu, na kar vplivajo aristokratski ženski portreti, kjer takšna postavitev poudarja vzvišen položaj portretiranke, hkrati pa je pri strogem profilu pogled upodobljenke odvrnjen od gledalca, kar velja za znamenje kreposti po tedanjih družbenih merilih, ki so spuščen ali odvrnjen pogled pojmovala kot znak ženske zmernosti, čistosti in pokornosti. ${ }^{11}$ Poročni

11 Origo, I., The World of San Bernardino, London, 1964, p. 68; sv. Antonin, Opera a ben vivere con altri suoi ammaestramenti (ed. Palermo F.), Firence, 1858, 164; Simons, P., Women in 
portreti v profilu so služili kot promocija nevestine kreposti in lepote ter ženinovega bogastva in ugleda, ki so ga predstavljala draga oblačila (najdragocenejši kos je bil rokav, na katerem so bili največkrat izvezeni heraldični motivi ženinove družine ali simboli rodovitnosti, kot je npr. granatno jabolko, ki je bila močno zaželena lastnost neveste) in nakit oz. dragi kamni, izmed katerih so bili v tedanjih Firencah najpriljubljenejši biseri, ki so s svojo okroglo obliko in belino simbolizirali popolnost in čistost. Slednje so pogosto vključevali na marijanske upodobitve.

Pomemben zasuk v florentinski ženski portretistiki 15. st. predstavlja upodabljanje $\mathrm{v}$ tričetrtinskem profilu, ki ga začne v sedemdesetih letih 15. st. Botticelli z Žensko na oknu (London, Victoria and Albert Museum), zakorenini pa ga Leonardova Ginevra de' Benci (slika 5). Odpre se pogled na obrazne poteze, zlate kodre, prsi, izrez se poveča, saj je upodobljenka naslikana v dopasni postavitvi, ki vključuje tudi roke, na kar vpliva kiparska umetnost (npr. Verrocchieva Dama š̌opkom).

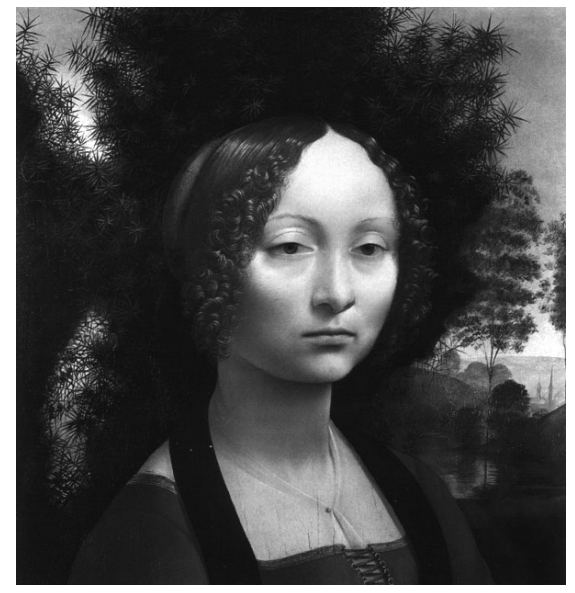

slika 5: Leonardo da Vinci: Portret Ginevre de’ Benci, 1475-80,

Washington, National Gallery of Art vir: Zöllner (2003)

Frames. The Gaze, the Eye, the Profile in Renaissance Portraiture, The Expanding Discourse. Feminism and Art History (eds. Broude, N., Garrard, M. D.), New York, 1992, 50; Casagrande, C., The Protected Woman, A History of Women in the West. Silences of the Middle Ages (ed. Klapisch-Zuber, C.), Cambridge, London, 1992, 95. 
$\mathrm{V}$ telo je vneseno gibanje, glava se obrne za devetdeset stopinj, sledi ji pogled, kar se sklada z umetnostno teorijo. Dama lahko gleda gledalca ali vstran. Če so oči obrnjene h gledalcu, se odpira vprašanje kreposti. Rešitev prinaša izraz pogleda, ki je resen, ponižen in nikakor ne zapeljiv. Z njim se ujema resni izraz na obrazu, ki ni nobena novost, saj je tak tudi na profilnih portretih. Druga rešitev je detajl cvetja, ki ga portretiranka drži v rokah in ga poklanja gledalcu oz. možu - takšna interpretacija pride $\mathrm{v}$ poštev pri poročnih oz. zaročnih portretih. Bistvena razlika s profilnimi portreti je v tem, da je sedaj bolj kot reprezentativna vloga poudarjena osebnost ženske. Njena obleka je običajno preprostejša, nakita je manj, slikarji pa se bolj osredotočajo na žensko samo. ${ }^{12}$ Ženska tako dokončno nastopi kot individuum.

Omeniti je potrebno tudi portrete idealiziranih lepotic, ki se povsem skladajo s poetičnim lepotnim idealom in prikazujejo ženske kot florentinske nimfe: zasnova je enaka kot na profilnih portretih, vsebinski poudarek pa je drugačen, saj v nasprotju z ženskimi portreti, ki predstavljajo krepost, izpostavljajo zapeljivo podobo ženske $\mathrm{z}$ erotičnimi poudarki (npr. s poudarjenimi prsmi, ustnicami, razvihranimi lasmi).

Takšni estetski normativi so botrovali nastajanju marijanskih upodobitev. Prehod iz realističnega v idealizirani marijanski lik se zgodi v opusu fra Lippija. Sprva njegova Marija ne deluje kot klasična lepotica petrarkističnega ideala, slikar spretno ubira srednjo pot med idealno lepim in realnim (slika 6). Na obraz ji nadene melanholičen izraz, s čimer ustvari povsem svojstveno izpovedno polje lepote in žalosti, materinske ljubezni in trpljenja. Melanholija je element, ki skupaj z realističnim obrazom izriše osebnostni pečat in Marijo predstavi kot žensko iz verniku poznanega sveta in zato dostopno. Takšno interpretacijo Miklós Boskovits razlaga kot vpliv karmeličanske tradicije na Lippija kot karmeličanskega meniha, za katero je bila značilna neposredna, živa verska vizija (Boskovits, 1986, 240).

Fra Lippi slika v tehniki tempere, ki je bila zakoreninjena v florentinskem slikarstvu, tudi mlajše generacije jo uporabljajo, šele Leonardo jo zamenja $\mathrm{z}$ oljem. Tempera ohranja distanco med podobo in gledalcem, saj ne

12 Posamezni profilni portreti ravno tako prikazujejo preprosto opravljene ženske, jih ne idealizirajo in se bolj posvečajo značaju (npr. Botticellijev Portret ženske iz ok. 1485 [Firence, Galleria Palatina]). 
zmore pričarati takšnega realističnega vtisa kot oljne barve, ki so jih v tem času uporabljali na Severu in ki Marijo predstavijo prepričljivo živo oz. realistično. Ker ne preseže okvirov imaginarnega likovnega sveta, je primerna za razvoj lepotnega ideala kot nerealne kategorije.

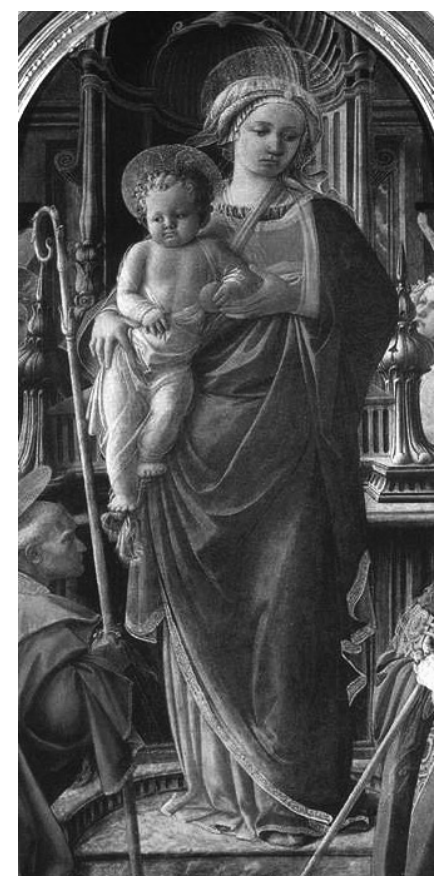

slika 6: Filippo Lippi: Marija z otrokom, angeli in svetnikoma (Barbadorijev oltar), 1437-39, Pariz, Musée du Louvre (detajl) vir: Ruda (1993)

Prelomnico v njegovem marijanskem opusu predstavlja tondo Marija $z$ otrokom, ki je verjetno nastal leta 1451 (Firence, Galleria Palatina) (slika 7). Mati božja je upodobljena kot nežno dekle z melanholičnim podolgovatim obrazom, kakršen zaznamuje Marijine podobe v poznem Lippijevem opusu. Ujema se s petrarkističnim lepotnim idealom, pred nami je svetlolaska bele polti, rjavih oči, elegantnih rok z dolgimi, tankimi prsti. Marija nosi broško z biseri, tančico dekorativno povija rdeč okrasni trak z zlatimi pikami, zelenkasto modri plašč in rdeča obleka sta obšita z zlato nitjo. Dokončno zapusti realistične okvire in postane idealno lepa. Marijanski tip, 
ki z bogato oblikovano pričesko in okrasom posega na področje profanega lepotnega ideala, je sveža pridobitev ne le za Lippija ampak za florentinsko slikarstvo 2. pol. 15. st., ki ta tip posvoji kot izhodišče idealizirajoče linije, ki doživi vrhunec $\mathrm{z}$ Botticellijem.

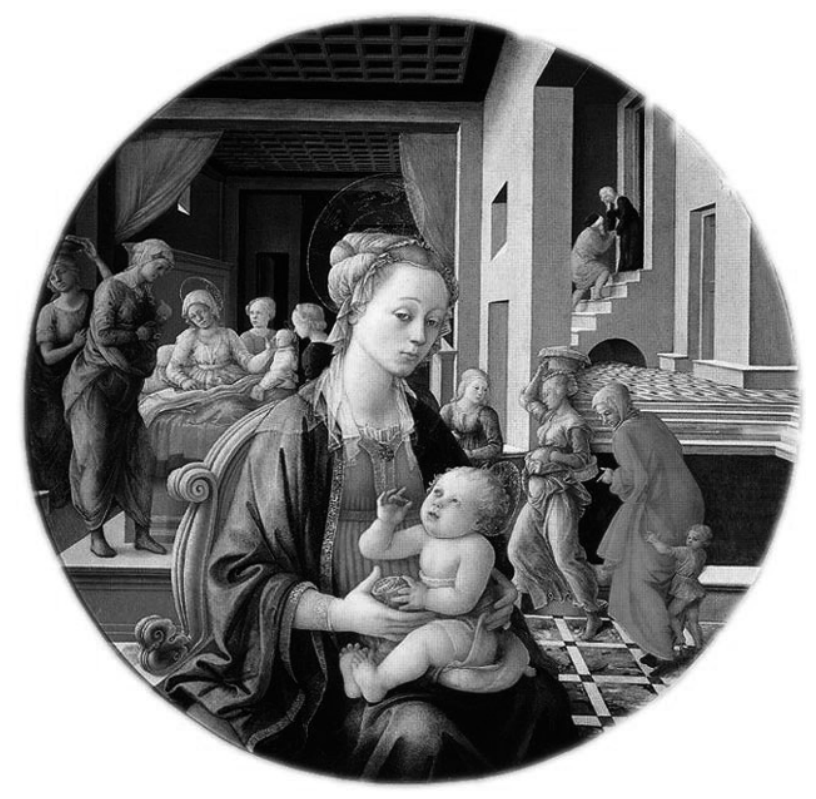

slika 7: Filippo Lippi: Marija z otrokom, ok. 1451, Firence, Galleria Palatina vir: Ruda (1993)

Kot prototip marijanskih upodobitev v florentinskem slikarstvu 2. pol. 15. st. lahko izpostavimo Marijo $z$ otrokom in dvema angeloma (Firence, Uffizi) (slika 8). Obraz in postavitev sta enaka pri sv. Marjeti na sliki Marija izroča pas sv. Tomažu iz 1455-65 (Prato, Galleria Comunale di Palazzo Pretorio), kjer je Lippi sodeloval s Fra Diamantejem. Marija je upodobljena v razkošni opravi kot Kristusova nevesta, spominja na sočasne ženske portrete. Eleganco poudarjajo linija glave, ki se nadaljuje v dolg bel vrat in okrogla ramena, ter dolgi tanki prsti. Spremembo lepotnega ideala povezujejo z Lucrezio Buti, redovnico iz samostana Santa Margherita v Pratu, ki jo Vasari opisuje kot dekle čudovite miline in videza, $v$ katero se je slikar 
zaljubil, ko mu je pozirala za sliko Marija izroča pas sv. Tomažzu ${ }^{13}$ (Vasari, Le vite, II, 620-621, 629). Mnenja o tej zgodbi so deljena, vendar se Marija iz galerije Uffizi časovno ujema $\mathrm{z}$ njunim razmerjem. Četudi ne moremo povsem zanesljivo povezati Lucrezie $\mathrm{z}$ Marijino podobo, pa se vendarle srečamo z mikavno hipotetično razlago, ko naj bi slikar, prevzet od lepote resnične ženske, prenesel poteze njenega obraza na Marijin lik.

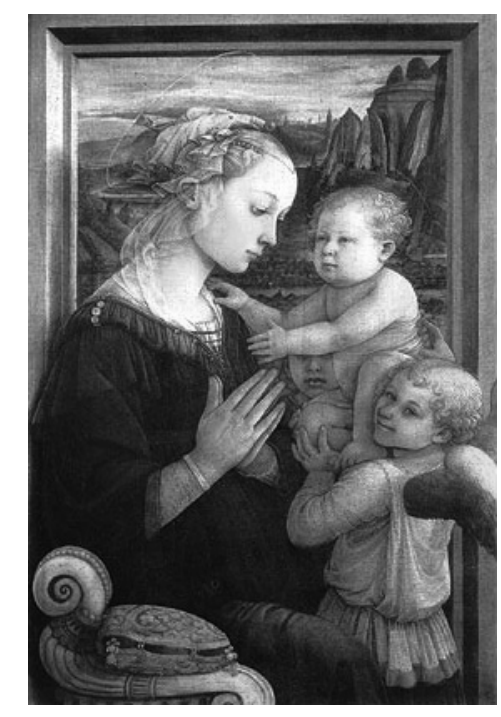

slika 8: Filippo Lippi: Marija z otrokom in dvema angeloma, 1465-69, Firence, Galleria degli Uffizi vir: Ruda (1993)

Ob tem se zastavlja vprašanje, koliko so se slikarji pri upodabljanju idealizirane Marije opirali na resnične ženske, se morda v kakšni Mariji skriva prikriti portret. Opozoriti velja na Savonarolovo pridigo o Amosu in Zahariji na soboto po drugi postni nedelji leta 1496, v kateri ošteje slikarje, da v likih svetnikov in Marije upodabljajo resnične ljudi in da »mladina govori tej in oni gospe: tole je Magdalena, tisti sv. Janez, glej, tale Devica; zakaj v cerkvah ste naslikali figure, ki so podobne tej ali oni ženski, kar je zelo slabo

13 Prim. Bandello, M., Le Novelle. La prima parte de le novelle del Bandello, III, London, 1791, 434-440. Nekateri avtorji so to zgodbo upoštevali, drugi so jo zavrnili kot plod domišljije. Gl. Ruda (1993, 40); Van Marle (1928, 430-432). 
in veliko zaničevanje Božjih stvari«(Savonarola, Prediche e scritti, 387). Ta praksa je bila očitno prisotna, vendar konkretnejših dokazov, žal, ni. ${ }^{14}$ Četudi najdemo posamezne sorodne poteze med kakšnim ženskim portretom in Marijo, se izkaže, da so idealizirane in posplošene, tako da gre za prenos lepotnega ideala na portrete in ne obratno (npr. Lippijev portret Angiole Sapiti [New York, Metropolitan Museum of Art], ki v obraznih potezah spominja na Marijo z Vizije sv. Bernarda [London, National Gallery]).

Lippijeva značilnost je melanholični izraz na Marijinem obličju, ki ga spremlja skozi celoten marijanski opus. Melanholija odpira večplastno razlago notranjega doživljanja, saj jo lahko interpretiramo kot modro, poduhovljeno figuro, lahko izraža materinsko ljubezen oz. skrb v slutnji prihodnosti. Otožnost, ki se mestoma povezuje z zasanjanim pogledom, močno vpliva na slikarska in kiparska dela z marijansko motiviko v 2. pol. 15. st.

To linijo razvoja nadaljuje Verrocchieva delavnica, v kateri se izobražujejo Botticelli, Leonardo, Ghirlandaio, Credi. Umetnikom je dala skupno izhodišče, ki ga opazimo v njihovih zgodnjih obdobjih, kasneje pa večinoma krenejo v lastno smer. Verrocchiev lepotni ideal predstavlja risba ženske glave iz Londona (British Museum), ki ga prevzamejo tudi učenci za časa učne dobe. Okrogli obrazek kasneje zamenja ožje obličje, za katerega se ne ve točno, kdo iz Verrocchieve delavnice ga razvije. Možno bi bilo, da začetni impulz predstavlja Leonardov angel s Krsta $v$ Jordanu (Firence, Uffizi), izpopolni pa ga z Marijo v skalni votlini (Pariz, Louvre). Uporabljajo ga slikarji Verrocchievega kroga (Botticelli, Ghirlandaio) in Verrocchio na svojih reliefnih in kiparskih delih.

Botticellijev lepotni ideal obsega več razvojnih faz. Zgodnje obdobje zaznamujejo vplivi fra Lippija in Verrocchia, omenimo le Marijo $z$ otrokom in dvema angeloma iz ok. 1468-69 (Neapelj, Museo di Capodimonte) (slika 9), kjer Botticelli povsem sledi poetičnemu lepotnemu idealu tako v obliki kot resnem, otožnem izrazu. Pred nami je utelešena Boccaccieva Emilia,

14 Tudi Botticellijevo domnevno upodabljanje Simonette Vespucci v njegovem idealiziranem ženskem tipu iz osemdesetih let 15. st. se je izkazalo za prenagljeno sodbo angleških avtorjev 19. st. Zgolj omenimo primer marijanskih upodobitev iz rimskega slikarstva za časa papeža Aleksandra VI., kjer je kot Marija upodobljena Giulia Farnese (npr. na fragmentu freske iz njegove spalnice, na freski nad vhodom $\mathrm{v}$ refektorij). 
manjkajo le kodrčki, saj so svetli lasje po Lippijevi maniri spleteni in zakriti $s$ tančico. Slikar s senčenjem ustvarja elegantno voluminoznost ter razkriva poznavanje anatomije, $s$ pravo mero združuje trdnost kostne podlage $\mathrm{z}$ mehkobo mišic in gladko kožo. Sledi Albertijevemu načelu reliefnosti, s katerim izpolnjuje sočasni slikarski ideal.

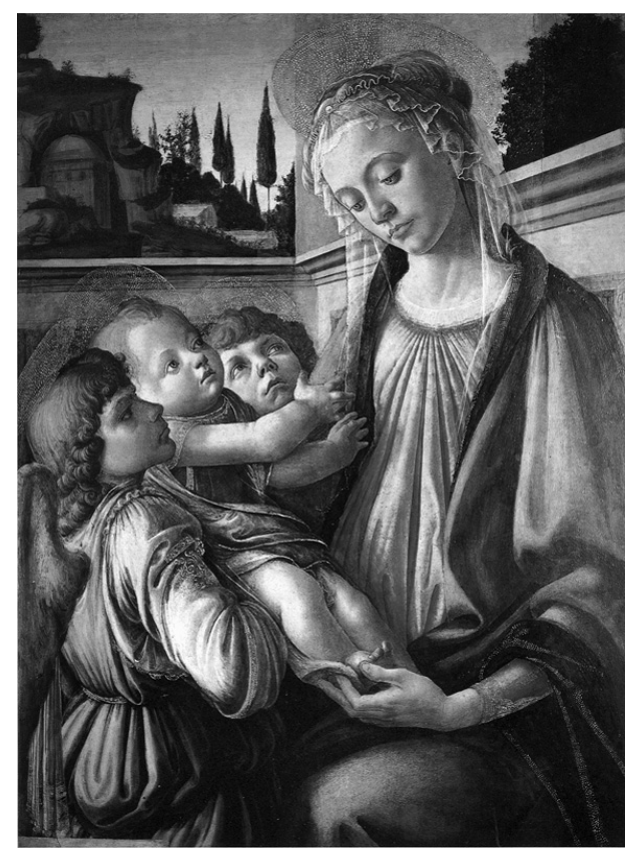

slika 9: Sandro Botticelli: Marija z otrokom in dvema angeloma, ok. 1468-69, Neapelj, Museo di Capodimonte vir: Vecchi, Arasse, Nelson (2004)

$\mathrm{Z}$ nagibom glave je slikar poudaril milino ter čustveni odnos matere do otroka in slutnjo Božjega načrta. Ta gib je Botticelli uporabljal tudi za druge ženske like (npr. za Fortitudo in Judito, Venero), je dediščina fra Lippija in Verrocchia. Otožnost je domala nepogrešljiva v vseh Botticellijevih obdobjih: prvotne Lippijeve vplive zamenja intenzivnejši obrat v melanholijo v osemdesetih letih, ki se stopnjuje do eterične duhovnosti in skupaj z distanciranostjo tvori jedro Botticellijeve interpretacije lepote.

V zgodnjem obdobju nastane tudi Evharistična Marija (Madonna Chigi) iz ok. 1470-72 (Boston, Isabella Stewart Gardner Museum) (slika 10). 


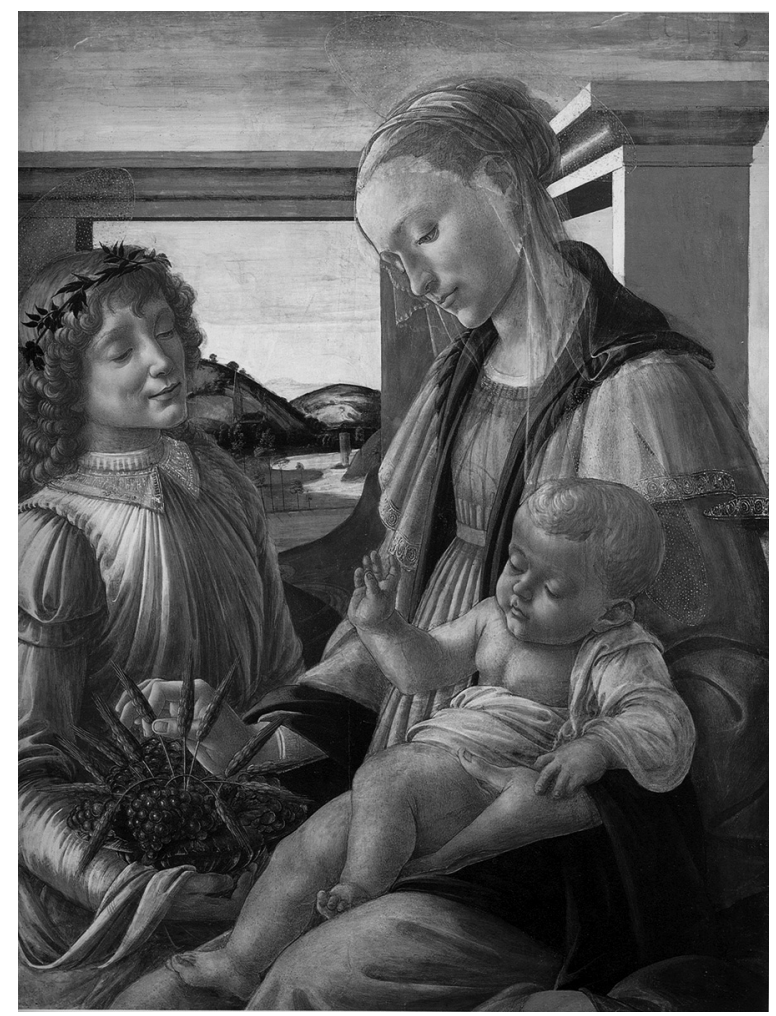

slika 10: Sandro Botticelli: Evharistična Marija (Madonna Chigi), ok. 1470-72, Boston, Isabella Stewart Gardner Museum vir: Vecchi, Arasse, Nelson (2004)

Marijin obraz je daljši, bolj reliefen oz. plastičen, saj je senčenje bolj dovršeno, ob strani ustnic se riše črta, ki daje obrazu ekspresiven, resen podton. Prefinjena modelacija obraz približuje kiparskemu značaju - takšen tip obličja predstavlja tudi Verrocchiev relief Marije $z$ otrokom (Firence, Museo Nazionale dell Bargello), soroden je Verrocchievi risbi ženske glave iz Oxforda (Christ Church College) tako v postavitvi kot izrazu in senčenju, čeprav so razlike v detajlih.

Ok. 1480 se začne pojavljati lepotni ideal, ki zaznamuje vrhunec Botticellijevega opusa in ki ga najdemo na tondih Marija $z$ otrokom in s petimi angeli (Madonna del Magnificat) iz ok. 1480-81 (Firence, Uffizi) ter Marija $z$ otrokom in s šestimi angeli oz. Marija $z$ granatnim jabolkom (Madonna della Melagrana) iz ok. 1487 (Firence, Uffizi) (sliki 11 in 12). 


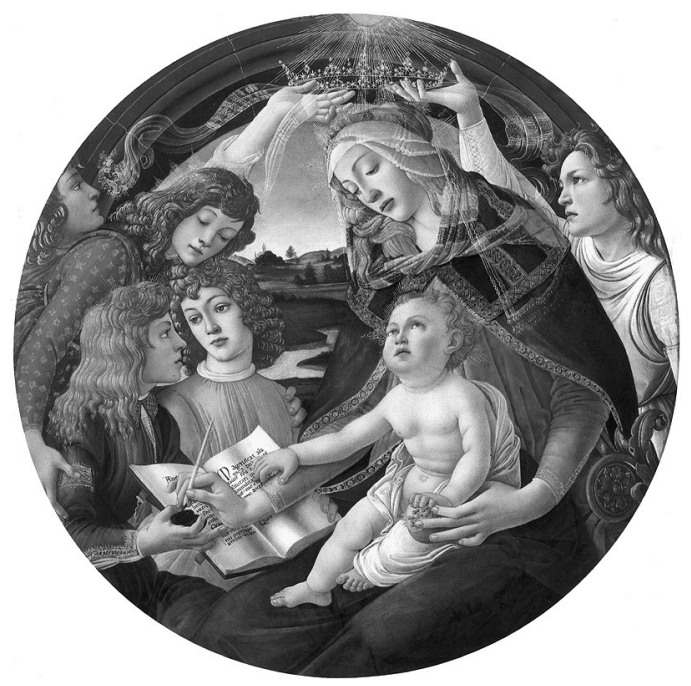

slika 11: Sandro Botticelli:

Marija $\mathrm{z}$ otrokom in s petimi angeli (Madonna del Magnificat), ok. 1480-81, Firence, Galleria degli Uffizi vir: Zöllner (2005)

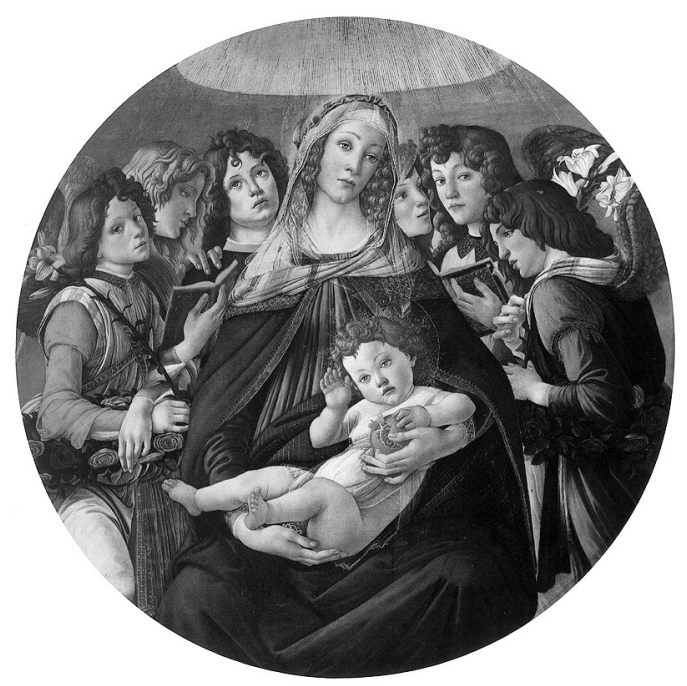

slika 12: Sandro Botticelli:

Marija $\mathrm{z}$ otrokom in s šestimi angeli oz. Marija z granatnim jabolkom (Madonna della Melagrana), ok. 1487, Firence, Galleria degli Uffizi vir: Zöllner (2005) 
Obličje je ožje, rahlo podaljšano, čelo je gladko in široko, ovalno formo zaključuje ozka brada $\mathrm{z}$ jamico. Svetli lasje sedaj zasijejo v zlatih odsevih, $\mathrm{s}$ čimer slikar izpolni merila poetičnega lepotnega ideala. Postava je vitka, telesno razmerje sledi merilu $1: 8$, dolg vrat se steka v zaobljena ramena, dolge in vitke roke delujejo elegantno, kar se ujema s pesniškim lepotnim idealom. Postave figur se zgledujejo po Veneri z Rojstva Venere (Firence, Uffizi), ki uteleša najbolj izpopolnjen Botticellijev lepotni ideal. Elegantno podobo dopolnjujejo roke, ki se po velikosti enačijo $\mathrm{z}$ višino obraza: prefinjeno formo podaljšanih proporcev zaključujejo dolgi tanki prsti. Slednji element je značilen za Verrocchievo delavnico in Leonarda, možen bi bil njun vpliv na Botticellija. Tako oblikovane roke se ujemajo s poetičnim lepotnim idealom. K prefinjenosti prispeva tudi mehko senčenje, ki ne ustvarja poudarjenega chiaroscura in $s$ katerim slikar zabriše prehode med obraznimi deli in da polti bleščeč, zglajen mladostni videz. Koža je svetla in nežna, kontrastirajo ji rožnato nadahnjena lica in nos ter majhne rožnate ustnice in rjave oči, temne obrvi, oblikovane v loku. $V$ tej fazi ni več verrocchievske reliefnosti, žrtvuje jo na račun zglajene polti. Spremembi lepotnega ideala bi utegnila botrovati Leonardova Marija $v$ skalni votlini.

Botticelli uspe s povezavo lepe forme, miline in melanholije kot idealnega temperamenta $\mathrm{v}$ renesančni miselnosti oblikovati idealno marijansko figuro, ficinovski prototip lepote: Marijina lepota ni zgolj zunanja, gledalec v obličju oz. liku prepozna bistvo njene osebnosti - ljubezen je temelj njene lepote, je odsev ideje lepote, Boga. Preko Marijine zunanjosti zahrepenimo po vzvišeni ideji lepote. Marija vodi gledalca od vidne, to je čutne zaznave lepega, h kontemplativnemu zrenju, hrepenenju po združitvi z Lepoto oz. Bogom, ki ga Ficino imenuje Ljubezen. Na te marijanske interpretacije lahko zremo tudi v smislu projekcije neoplatonistične filozofije v slikarski slog: Botticelli se oddaljuje od resničnosti, saj ne slika v realističnem slogu, temveč razvija umetelne like, ki ostajajo na nivoju imaginarnega sveta lepote, miline in sijaja. Idealiziranje bi lahko primerjali z neoplatonističnim svetom idej, saj uteleša popolnost, ideal zmaguje nad resničnim, umetelno nad naravnim. Botticelli je v tem smislu idealni neoplatonistični umetnik, njegovo delo je vizualizirana Ficinova filozofija.

V devetdesetih letih 15. st. se lepotnost in milina umikata dostojanstvu in hierarhični vrednosti. Marija je osrednja figura kompozicije, običajno je 
večja od ostalih, s čimer Botticelli poudari njen pomen in duhovno veličino (slika 13). Telesni proporci se v nekaterih primerih spremenijo, razmerje med višino glave in telesa znaša lahko tudi $1: 6,5$, zato Marija deluje groteskno. Slikar se bolj kot na zunanjo lepoto osredotoča na ekspresivnost obrazi so polni meditativne zamaknjenosti, mestoma asketske melanholije. Marija postane simbolna figura, ki izžareva moč Božje oblasti in prerašča $\mathrm{v}$ personifikacijo Eklezije.

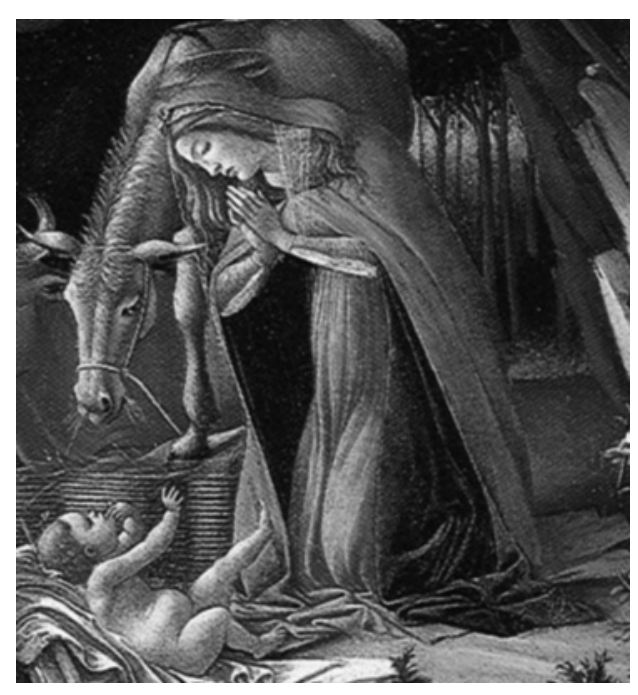

slika 13: Sandro Botticelli: Mistično rojstvo,1501, London,

National Gallery (detajl)

vir: Vecchio, Arasse, Nelson (2004)

Fra Lippi in Botticelli vplivata na Filippina Lippija, ki nadaljuje linijo idealiziranega marijanskega tipa, vendar že v zgodnjem obdobju išče lastne rešitve v oblikovanju ženskega lepotnega ideala. Njegove Marije lahko umestimo v skupino, na katero vpliva petrarkistični lepotni ideal, vendar nekatere odstopajo v posameznih detajlih (npr. temnorjavih laseh). Večinoma so elegantne, sloke figure, upodobljene v telesnem razmerju 1: 9 (mestoma uporablja telesno razmerje 1:8), kar se razlikuje od Albertijevega in Botticellijevega sistema telesnih razmerij (slika 14). Filippinov slog temelji na risbi, ki pa ni tako poudarjena kot pri Botticelliju, in nežnem modeliranju, rezultat česar je gracilna figura, ki deluje nezemeljsko. Tudi njegova Marija 
je melanholično zasanjan lik, upodobljena je kot resna mlada žena, ki ponižno in ljubeznivo izpolnjuje svojo vlogo Odrešenikove matere. Filippino zaključuje tisto smer idealizirajočega toka v florentinskem slikarstvu 2. pol. 15. st., ki jo začne fra Lippi, nadaljujeta Verrocchiev krog in predvsem Botticelli: je nežen in umirjen lik, s svojo sladkostjo uteleša ženski lepotni ideal iztekajočega se 15 . st.

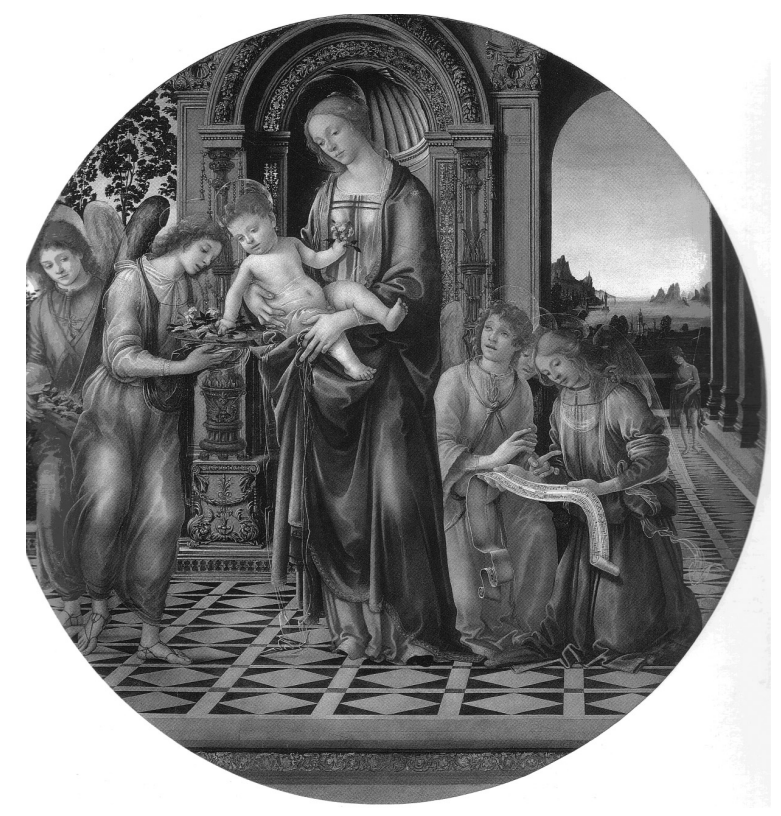

slika 14: Filippino Lippi: Marija z angeli, ok. 1482-83, Firence, Ente Cassa di Risparmio di Firenze vir: Vecchio, Arasse, Nelson (2004)

Leonardo sprva posnema Verrocchiev ideal, kakršnega vpelje z risbo ženske glave iz Londona (npr. Marija $z$ nageljnom iz sedemdesetih let 15. st., München, Alte Pinakothek), nato lepotni tip postopoma razvija, vmesno stopnjo predstavlja Madona Benois iz 1478 (Sanktpeterburg, Gosudarstvennyj Ermitaž) (slika 15), kjer je obraz v zasnovi okrogel, vendar v detajlih brade, ust in nosu ter nagnjene glave kaže nadaljnji razvoj obraznega tipa. Leonardo raziskuje tudi sfumato, s katerim doseže izredno mehkobo polti, $\mathrm{k}$ čemur doprinese tudi oljna tehnika, ki jo uporablja do konca opusa. 


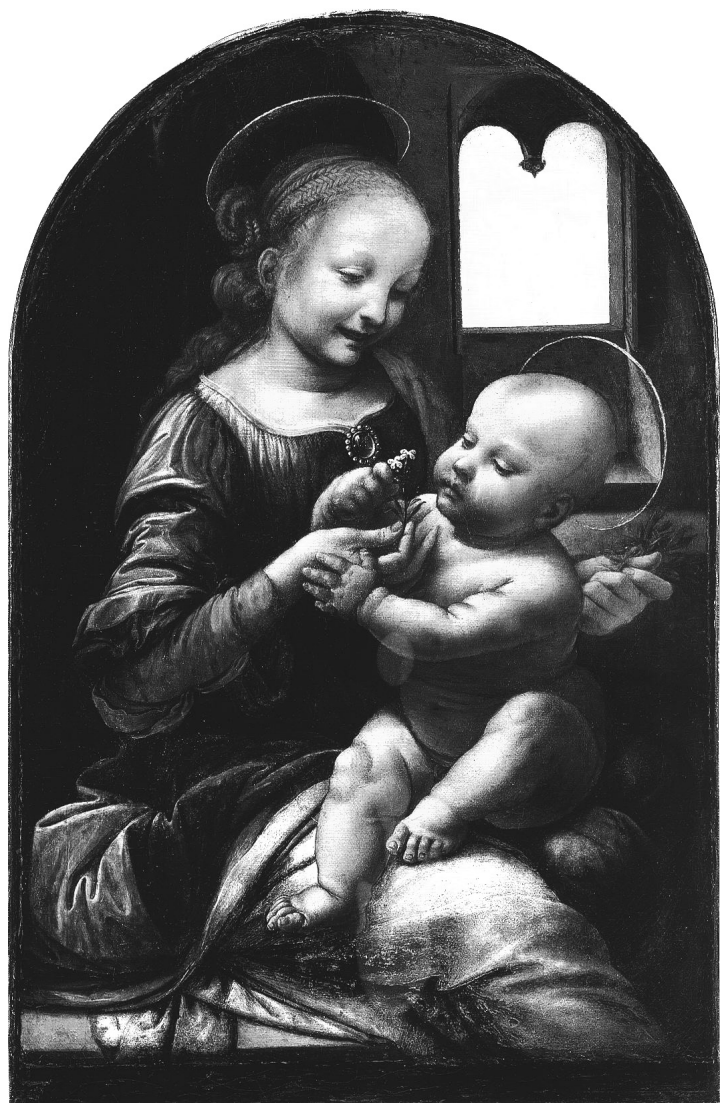

slika 15: Leonardo da Vinci: Madona Benois, 1478, Sanktpeterburg, Gosudarstvennyj Ermitaž vir: Zöllner (2003)

Vrhunec predstavlja Marija v skalni votlini iz 1483-86 (Pariz, Louvre) (slika 16). Ozko obličje z dolgim tankim nosom in visokimi ličnicami deluje blago in ljubeznivo, $\mathrm{k}$ čemur prispeva povezava sfumata, nagnjene glave, spuščenega pogleda in latentnega nasmeška. Sfumato razprši senco in kožo naredi svilnato, Marija deluje večno mlada, vendar ni več dekliški lik, kot je bila v zgodnjem Leonardovem obdobju, ampak postane zrelejša. Njena duhovna podoba se kaže v izrazu na obrazu, drži in odnosu do otroka, do katerega goji materinsko ljubezen, hkrati pa se zaveda njegovega poslanstva in s tem tudi svojega. 


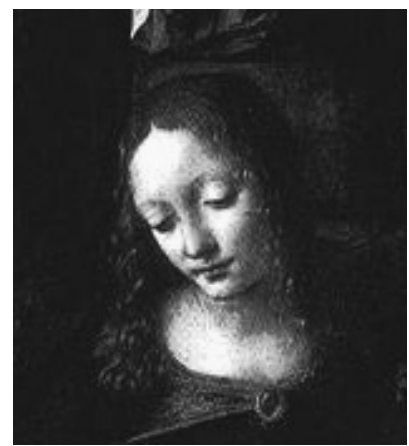

slika 16: Leonardo da Vinci: Marija v skalni votlini, 1483-86,

Pariz, Musée du Louvre (detajl) vir: Zöllner (2003)

Leonardo upošteva lastna teoretična izhodišča $\mathrm{v}$ telesnih proporcih (1 : 8), senčenju, razgibanosti figure, psihološkem izrazu, oblikovanju pričesk (lasje so ukročeni) in preprosti opravi (mestoma Marijin plašč spenja broška $\mathrm{z}$ dragimi kamni, kakršno pozna Verrocchieva delavnica). Njegova Marija je rjavolaska, kar odstopa od petrarkističnega lepotnega ideala, ohrani kodre, ki zasijejo na svetlobi. Bistveno novost predstavlja sfumato kot sredstvo za upodabljanje miline, zato Marijina podoba deluje bolj mistično, eterično. Oljna tehnika je ključnega pomena za sam način senčenja kot tudi tehnika slikanja s prsti, ${ }^{15}$ saj se na ta način dosežeta mehkoba in gracilnost polti. Spremenjen obrazni tip vpliva na Marijin izraz, deluje bolj elegantno in poduhovljeno in ne le kot sladka Devica, ki pripada nebeški sferi.

Svojstven prispevek prinesejo Ghirlandaiove marijanske upodobitve, ki se razlikujejo od sočasnih predvsem v realistični obravnavi figure, ki jo s stopnjevanim senčenjem predstavi izredno plastično, voluminozno (sli-

15 Konservatorska dela so pokazala, da je Leonardo na marsikateri sliki (npr. na Oznanjenju iz florentinske galerije Uffizi, londonski Mariji v skalni votlini) za upodabljanje sfumata uporabljal prste, saj naj bi nežno tkivo prstnih blazinic služilo kot najnežnejše orodje za ustvarjanje odtenkov, ki jih je želel naslikati. Gl. Gage, J., Colour and Culture. Practice and Meaning from Antiquity to Abstraction, London, 1995, 135. V Verrocchievi delavnici je slikanje s prsti povezano $\mathrm{z}$ uvedbo oljne tehnike, vendar učinka prosojnosti barv niso takoj obvladali. Če je Leonardo začel s to tehniko, je bil razlog v tem, da bi čim hitreje izkoristil značilni sijaj oljnih barv, a dolgoročno je bila to le zasilna rešitev. Takoj ko je znal s čopičem doseči vibriranje svetlobe, se je dokončno odpovedal slikanju s prsti. Gl. Arasse (2003, 318-319). 
ka 17). V tem se približuje sočasnemu nizozemskemu slikarstvu, ki vpliva nanj $\mathrm{z}$ realistično podanimi kompozicijami in natančnimi detajli, vendar ostaja Ghirlandaio v mejah omiljenega realizma.

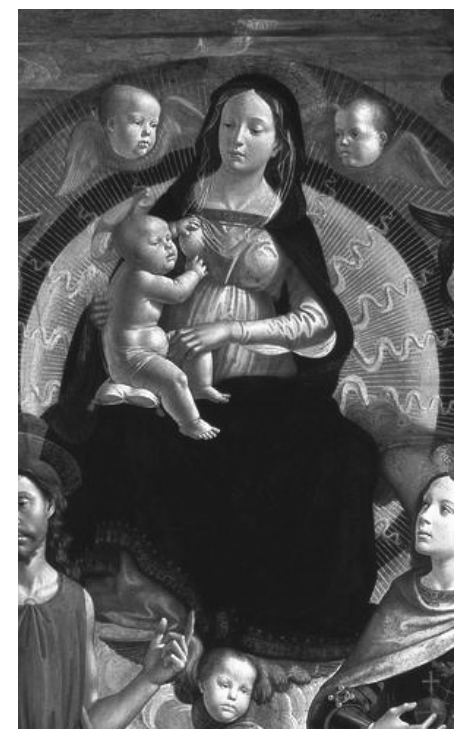

slika 17: Domenico Ghirlandaio:

Marija v slavi s svetniki (Pala Tornabuoni), ok. 1490-96, München, Alte Pinakothek (detajl)

vir:http://www.pinakothek.de/alte-pinakothek/sammlung/kuenstler/kuenstler_ inc_en.php?inc=bild\&which $=4432$

Voluminoznost oz. plastičnost lahko primerjamo z Masaccievo, skupni so jima tudi jasni obrisi cele figure in detajlov (npr. obraznih delov). Ghirlandaio upošteva določila poetičnega in teoretičnega lepotnega ideala, pomembno izhodišče predstavlja Verrocchieva delavnica, vendar se kasneje slikar omeji le na njene posamezne značilnosti (ornament, nakit), slogovno pa razvije lasten lepotni tip. Za razliko od svojih sodobnikov in predhodnikov se $\mathrm{v}$ večini primerov odpove melanholičnemu značaju Matere božje oz. ga močno omili. Njegove Marije kot razumne žene predstavljajo nasprotje emocionalno izraznim figuram verrocchievske in botticellijevske usmeritve, zato večkrat dobimo vtis, da kljub uporabi značilnih elementov za predstavitev miline (spuščenega pogleda in nagnjene glave) Marijina duhovna podoba ni docela razvita in je zato poudarek predvsem na formi. 
Morda zato nekatere njegove Marije delujejo manj intimno zaupljivo, v nasprotju z Botticellijem, in je njihovo vrednost potrebno iskati v slovesni reprezentativnosti.

Idealizirani marijanski tip je v florentinskem slikarstvu 2. pol. 15. st. povsem prevladal, nekoliko se stanje spremeni v devetdesetih letih, ko se družbene razmere spremenijo in se poudarja teološka vsebina, vendar je le pri nekaterih slikarjih opaziti manj idealiziran, ekspresiven lik (npr. pri Botticelliju in Filippinu Lippiju). Omeniti velja tudi realistične interpretacije Luce Signorellija in Piera di Cosima, ki pa so manj številne. Idealizirajočo maniro so slikarji, kot so Leonardo, Filippino Lippi in Perugino, zanesli v zgodnje 16. st. in odprli vrata visokorenesančnim marijanskim upodobitvam $\mathrm{z}$ Rafaelom na čelu.

Florentinskim slikarjem 2. pol. 15. st. je uspelo spretno povezati notranjo in zunanjo lepoto ter vernikom predstaviti Marijo kot najlepšo med ženami. Z Marijino lepoto so uspeli seči v srce gledalcu in ga spodbuditi $\mathrm{k}$ razmišljanju o presežnem. Tako lahko še danes z nekoliko nostalgičnim pogledom doživljamo te marijanske upodobitve kot odsev časa, ki je častil lepoto ne le kot najvišji umetnostni ideal temveč tudi kot temeljni cilj človekovega bivanja.

\section{VIRI}

Alberti, L. B., L' architettura [De re aedificatoria]. Testo latino e traduzione a cura di Giovanni Orlandi. Introduzione e note di Paolo Portoghesi, II, Milano, 1966.

Alberti, L. B., On painting. Translated with introduction and notes by John R. Spencer, New Haven, London, $1966^{2}$.

Aurelius Augustinus, De Trinitate, VIII-XI, XIV-XV, Anhang: Buch V. Neu übersetzt und mit Einleitung herausgegeben von Johann Kreuzer. Lateinisch-deutsch, Hamburg, 2001.

Ficino, M., Commentary on Plato's Symposium on Love (prevod Jayne, S.), Woodstock, Connecticut, 1999. 
Ficino, M., Opera (ed. Pelé, G.), Pariz, 1641.

Ficino: Opera omnia (ed. Sancipriano, M.), Torino, 1959.

Ficino, M., Platonic Theology, III, IX-XI (prevod Allen, M. J. B., Warden, J., eds. Hankins, J., Bowen, W.), XI, iv, 21, Cambridge, London, 2003.

Lorenzo de’ Medici, Ausgewählte Werke. Opere scelte, Tübingen, 1998.

Petrarca, F., Soneti in kancone (prevod Gradnik, A.), Koper, 1954.

Poliziano, A., Stanze per la giostra. Orfeo. Rime (ed. Maier, B.), Novara, 1969.

Pulci, L., Morgante (ed. Ageno, F.), Milano, Neapelj, 1955.

Savonarola, G., Prediche e scritti. Con introduzione, commento, nota bibliografica e uno studio sopra 'L' influenza del Savonarola su la letteratura el' arte del quattrocento' di Mario Ferrara, Milano, 1930.

Vasari, G., Le vite de' più eccelenti pittori scultori ed architettori scritte da Giorgio Vasari pittore Aretino con nuove annotazioni e commenti di Gaetano Milanesi, Firence, 1906.

Leonardo da Vinci, Traktat o slikarstvu (prevod Jurca, T. in Žlender, M.), Ljubljana, 2005.

Vitruvij, Deset knjiga o arhitekturi [De architectura libri decem] (prevod Lopac, M. in Bedenko, V.), Zagreb, 1999.

\section{LITERATURA}

Arasse, D., Léonard de Vinci. Le rythme du monde, Pariz, 2003.

Baxandall, M., Slikarstvo in izkušnja v Italiji XV. stoletja. Začetnica iz socialne zgodovine slikovnega stila (prevod Zabel, I.), Ljubljana, 1996.

Bellosi, L. (ur.), Masaccio e le origini del Rinascimento, Milano, 2002.

Borsi, F. in S., Paolo Uccello, London 1994.

Boskovits, M., Fra Filippo Lippi, i Carmelitani e il Rinascimento, Arte cristiana, LXXIV, 1986, 235-252.

Brown, D.A. (ur.), Virtue \& beauty. Leonardo's Ginevra de Benci and Reanissance portraits of women, Oxford, 2001. 
Brown, D. A., Introduction, v: Brown, D.A. (ur.), Virtue \& Beauty. Leonardos Ginevra de'Benci and Reanissance portraits of women, Oxford, 2001.

Clark, K., The nude. A study of ideal art, London, 1956.

De Vecchi, P., Arasse, D. in Nelson, J.K. (ur.), Botticelli e Filippino. L'inquietudine e la grazia nella pittura fiorentina del Quatrocento, Milano 2004.

Dempsey, C., Portrayal of Love. Botticelli's Primavera and Humanist Culture at the Time of Lorenzo the Magnificent, New Jersey, 1992.

Durant, W., The Renaissance. A History of Civilization in Italy from 13041576 A. D., New York, 1953.

Hersey, G. L., The evolution of allure. Sexual selection from the Medici Venus to the Incredible Hulk, Massachusetts, 1996.

Holmes, M., Fra Filippo Lippi. The Carmelite Painter, New Haven, London, 1999.

Van Marle, R., The development of the Italian schools of painting, X, Haag, 1928.

Mikuž, J., Kri in mleko. Sugestivnost podobe, I, Ljubljana, 1999.

adke, G. M., Masaccio's City, v: Ahl, C.D. (ur.), The Cambridge Companion to Masaccio, Cambridge, London, 2002, 40-63.

Richter, J. P., The Literary Works of Leonardo da Vinci, I, Oxford, 1939.

Rubin, P.L., Wright, A., Renaissance Florence. The Art of the 1470s, London, 1999.

Ruda, J., Fra Filippo Lippi. Life and Work, London, 1993.

Simons, W., Reading a Saint's Body, Rapture and Bodily Movement in the Vitae of Thirteenth-Century Beguines, v: Kay, S., Rubin, M. (ur.), Framing Medieval Bodies, Manchester, New York, 1994, 10-23.

Trexler, R. C., Ritual Behaviour in Renaissance Florence: the Setting, Church and Community 1200-1600: Studies in the History of Florence and New Spain, Rim, 1987, 11-36.

Zöllner, F., Leonardo da Vinci 1452-1519. The Complete Paintings and Drawings, Köln, 2003.

Zöllner, F., Sandro Botticelli, München, 2005. 


\title{
IDEAL BEAUTY IN DEPICTING THE VIRGIN MARY IN FLORENTINE PAINTING IN THE SECOND HALF OF THE FIFTEENTH CENTURY
}

\author{
Keywords: ideal beauty, Florentine renaissance, Virgin Mary, renaissance \\ painting
}

\section{Abstract}

An idealized type of Virgin Mary prevails in Florentine painting of the second half of the fifteenth century. Painters depicted Mary according to Florentine art theory, philosophy, and poetry of the fifteenth century as a woman of physical and spiritual beauty. Ideal female beauty was very precisely defined and it was used not only for images of the Virgin but also for other female figures in art - and, as can be seen from contemporary female portraits, it was also followed by Florentine women (and women from some other Italian regions as well) in the fifteenth century.

Treatises on painting by Leon Battista Alberti and Leonardo da Vinci were very important for the development of the idealized human figure in Florentine fifteenth-century art theory. Both authors agreed that nature is the only true source of beauty, but they urged painters to select the most beautiful parts of nature and create a new, ideal whole. They emphasized the significance of shading, and da Vinci considered sfumato a means of beauty. Both authors connected body movements with inner feelings, "movements of the soul;" movements must coincide with inner feelings. They presented the ideal proportions of the human body: Alberti's figure measures 7.5 head heights and Leonardo's 8 , and both proportional systems can be found in Florentine fifteenth-century painting.

Marsilio Ficino, the leading Florentine renaissance Neoplatonist, defined beauty as an idea that dwells in the world of ideas and shows itself in the terrestrial world as beautiful bodies. He connected beauty with good, and considered beauty as a splendor of good. 
Poetry of the Medici circle presented idealized women with much in common: they had blonde hair with shiny curls, pale skin, dark sparkling eyes, a long neck, round shoulders, a slim waist, long elegant arms and legs, and small feet. The ideal woman was virtuous, intelligent, and pious. She smiled so lovingly that she could open the gates of Heaven. Descriptions of female beauty originate in earlier poetry, such as troubadour lyrics and the works of Dante, Petrarch, and Boccaccio. These descriptions influenced Medicean poets such as Luigi Pulci, Agnolo Poliziano, and Lorenzo de' Medici.

Fra Filippo Lippi represents an important starting point in depicting the idealized Virgin Mary in Florentine painting of the second half of the fifteenth century. His ideal beauty was based on poetics, and the painters of Andrea del Verrocchio's workshop followed it. One of these painters was Sandro Botticelli, who represents the peak of the trend in idealized depictions of Mary. Botticelli connected the beautiful form, grace, and melancholy into an ideal figure of Mary. His paintings of the Virgin can be understood as an allusion to Ficino's philosophy: the Virgin is complete in form and spiritual beauty; she is an image of the ideal that embodies perfection and rises above terrestrial beauty. This idealizing manner was concluded by Botticelli's pupil Filippino Lippi with a sweet and gentle Virgin.

Leonardo da Vinci initially followed Verrocchio's ideal beauty of a round face and ornamented hairstyle, but later developed his own ideal beauty of a narrow face, high cheekbones, and a gentle smile. Sfumato is used to depict the soft skin and her ethereal expression.

Domenico Ghirlandaio developed his own ideal of female beauty. $\mathrm{He}$ concentrated on plastic form, and his Virgin is less melancholy than his contemporaries'.

Florentine painters of the second half of the fifteenth century succeeded in connecting the spiritual and physical beauty in Virgin Mary and depicting her as the most beautiful woman that ever lived. 